\title{
Lithofacies and Depositional Environment of Volcano-Sedimentary Deposits of Se Mayo Oulo Basin
}

\author{
${ }^{1}$ Elie Fosso Menkem, ${ }^{1}$ David Sebag, ${ }^{2}$ Benjamin Ngounou Ngatcha and ${ }^{1}$ Alain Durand \\ ${ }^{1}$ Department of Geology, UMR CNRS 6143, University of Rouen, France \\ ${ }^{2}$ Department of Geology, University of Ngaoundere, Cameroon
}

Received 2013-11-30; Revised 2013-12-12; Accepted 2013-12-19

\begin{abstract}
The study of volcano-sedimentary deposits of Mangbai in SE Mayo Oulo basin-Cameroon leads to the identification of five major distinct lithofacies types. From the coarset to the finest lithofacies, there are: Gb-clast supported by massive coble and boulder, Gg-granule to massive gravel, Sm-massive sand, Shhorizontal layered sandstones, Fml-massive laminated claystones. Coarse facies $(\mathrm{Gb}, \mathrm{Gg}, \mathrm{Sm})$ are cemented with volcanic matrix while the finest facies (Sh, Fml) are normal sedimentary compacted deposits. The coarsest facies distribution is identified on the top SE of the mountain while the medium to finest facies deposits are located at the base of the sequence. The formation of the volcano-sedimentary deposits of Mangbai are associated to the development and establishment of Africa major rift system while sedimentary deposits in the Mayo Oulo basin are more recent and date from Lower Cretaceous.
\end{abstract}

Keywords: Volcano-Sedimentary, Lithofacies, Depositional Environments, Tectonic Extension, Mayo Oulo

\section{INTRODUCTION}

The Mayo Oulo sedimentary basin is located in the North-Cameroon (Fig. 1). The Katiau Mountains also known as Mangbai Mountains are part of this sedimentary basin. They are located to the SE near the Kakou village and the lake Kebi mainly supplied by the Mayo Oulo river. In the Mangbai Mountains, complex facies of volcano-sedimentary deposits are visible. These volcano-sedimentary rocks facies outcropping are either superimposed or associated to pure sedimentary deposits. Detailed sedimentological and tectonic studies of the Mayo Oulo basin have previously been conducted by Brunet et al. (1988); Maurin and Guiraud (1989; 1990) and Ndjeng and Brunet (1994; 1998). Nevertheless, these works have never been integrated to their study the volcano-sedimentary deposits of the Mangbai formation into the Mayo Oulo basin evolution. Studies carried out by (Bea et al., 1990) have enabled the characterization of the volcanic rocks of the regions of Mangbai, Balche and reconstruct the tectonic and volcanic history of North Cameroon Grabens. This study intends to reconstruct lithofacies evolution and depositional environments of Mangbai Mountain by presenting detailed field observations data and interpretation. Our study will consist in the description of main lithofacies (Table 1) and associated microfacies cropping out in the SE part of the Mayo Oulo basin. The main encounter of lithofacies have been interpreted and classified according to grain size (Table 1). These preliminary studies will allow us to reconstruct the depositional and tectonic history of SEMayo Oulo and regional basin evolution.

\section{MATERIALS AND METHODS}

Samples were taken in accordance to facies variation and were obtained from different localities. In addition, a total of 35 thin sections were studied, based on facies variation allowing identification of relevant microfacies composition and source rock.

Corresponding Author: Elie Fosso Menkem, Department of Geology, UMR CNRS 6143, University of Rouen, France 


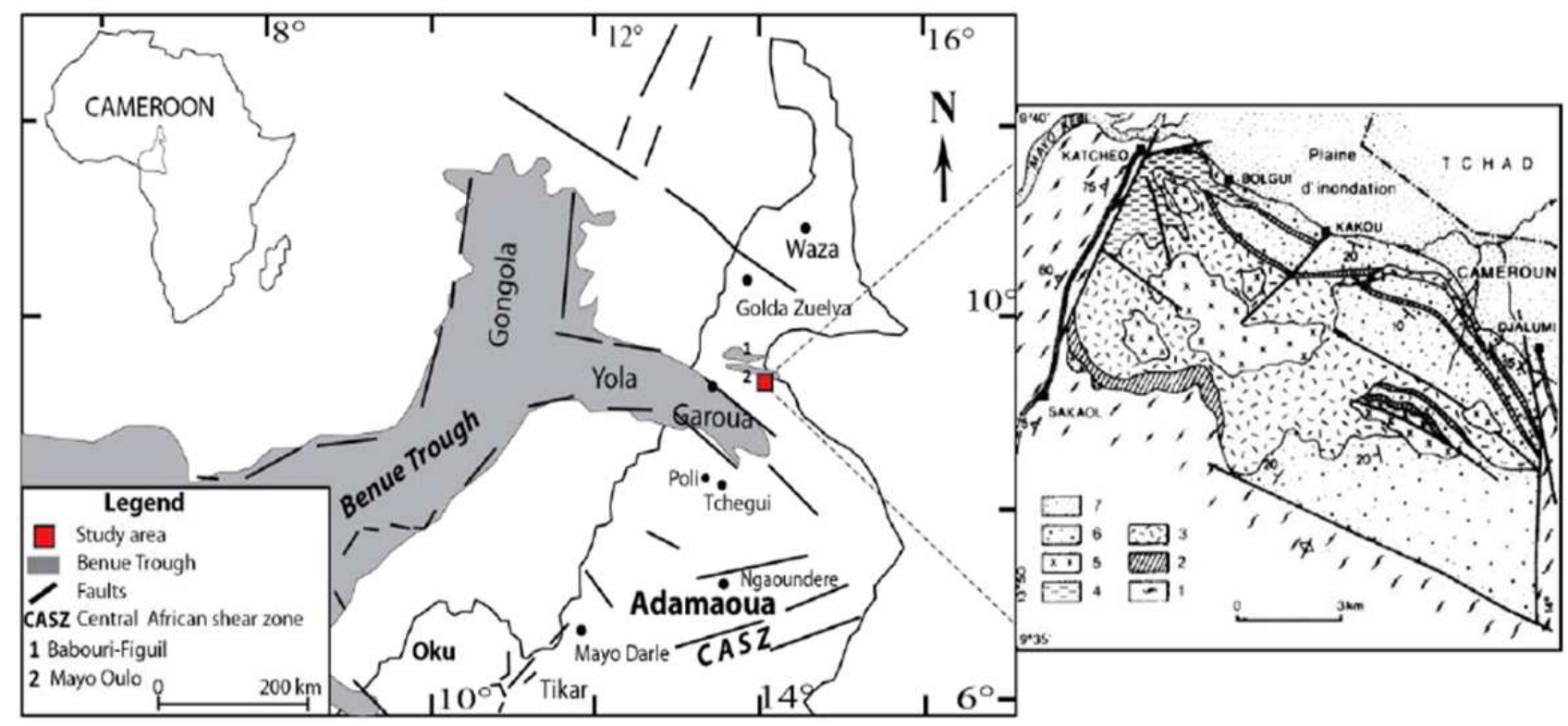

Fig. 1. Location map of study area; the Cameroon map is redraw and adapted on the basis of geological map of Montigny et al. (2004). The geological map of Mangbai is from Bea et al. (1990). 1: Precambrian Basement, 2: Basalts, 3: Trachy-andesites, 4: Ignimbrites, 5: Rhyolites, 6: Sandstones and conglomerates, 7: alluvials deposits

Table 1. Lithofacies types of the volcano-sedimentary formation of Mangbai

\begin{tabular}{|c|c|c|}
\hline Facies code and name & Lithology description & Interpretation \\
\hline $\begin{array}{l}\text { Gb: clast supported } \\
\text { massive coble and } \\
\text { boulder }\end{array}$ & $\begin{array}{l}\text { Clast supported, massive coble and boulder. } \\
\text { few decimeters to meters thick. Clasts range from } 1 \mathrm{~cm} \text { to } \\
\text { about } 1 \mathrm{~m} \text { in diameter and consists of fragmented granites, } \\
\text { basalts,rhyolites and trachyte. }\end{array}$ & $\begin{array}{l}\text { Bedload gravel, higher discharge debris flow } \\
\text { from gravity and lavas flow. Clasts are } \\
\text { cemented by lavas and poor sandstone matrix. }\end{array}$ \\
\hline $\begin{array}{l}\text { Gg: granule to massive } \\
\text { Gravel }\end{array}$ & $\begin{array}{l}\text { Chaotic deposits. Clasts from pebble to coble, spherical, poorly } \\
\text { sorted. Light grey to brown, fine to medium. Granites, basalts } \\
\text { and quartz,poorly sorted, erosive base, massive beds. }\end{array}$ & Longitudinal bedforms \\
\hline Sm: massive sand & $\begin{array}{l}\text { Medium to coarse sands grains, sub-rounded to spherical, grey and } \\
\text { black. Massive, presence of pebble, poorly sorted, massive beds. }\end{array}$ & Migration of longitudinal bedforms \\
\hline $\begin{array}{l}\text { Sh: Horizontal layered } \\
\text { Sandstones }\end{array}$ & $\begin{array}{l}\text { Very fine to medium grains sands, sub-rounded to rounded quartz } \\
\text { grains, well sorted. Thin to medium parallels beds, } 2 \text { to } 50 \mathrm{~cm} \text {. }\end{array}$ & Lake floor suspension deposits \\
\hline $\begin{array}{l}\text { Fml: Massive laminated } \\
\text { Claystones }\end{array}$ & $\begin{array}{l}\text { Claystones, grey to reddish, grading to fine siltstones. } \\
\text { Thin laminated parallels beds. }\end{array}$ & $\begin{array}{l}\text { Low energy deposits from suspension and } \\
\text { precipitation. Lake floor suspension deposit }\end{array}$ \\
\hline
\end{tabular}

The tectonic evolution of basin based on the field observation data, tectonic map analysis and available literature was considered in order to highlight the interpretation of sedimentary deposits architecture and tectono-sedimentary evolution of the basin. The facies codes used are modified based on Miall $(1978 ; 2010)$. The term "Mayo" refers to "River" and Hossere designate mountains in Fufulde language.

\section{RESULTS}

Lithofacies and microfacies are analyzed based on lithology, texture, internal sedimentary structure, grain size and boundary condition. Five major's lithofacies (Table 1) were identified. They were gathered into three majors groups of lithofacies, namely: conglomerates, sandstones and claystones.

\subsection{Lithofacies Analysis and Interpretation of Mangbai Formation}

\section{Gb: Clast Supported Massive Coble and Boulder}

Lithofacies $\mathrm{Gb}$ is dominant on the upper SE part of the mountain Hossere Katiau. Clasts and breccias are very coarse. They consist of fragments of granite, basalt, gneiss, trachyte and rhyolite partially cemented during 
the transportation process by fine to medium sandstone in the lower part and with basalt flows on the upper part. The average diameter of the clasts ranges from $10 \mathrm{~cm}$ to more than $1 \mathrm{~m}$ (Fig. 2a and b) and are angular to subangular, poorly rounded to poorly sorted and deposited as a result of transport by gravity and bedload associated with volcanic flows. There is no visible stratification for these massive conglomeratic deposits. Lithofacies $\mathrm{Gb}$ are interpreted as being formed "in the channel" and are spreading sediment deposited during major floods. Miall (1978) characterizes the lithofacies $\mathrm{Gb}$ as deposits of "Matrix-supported" and "boulder-dominated" types; which are dominated by mass transport deposits resulting in debris flows.

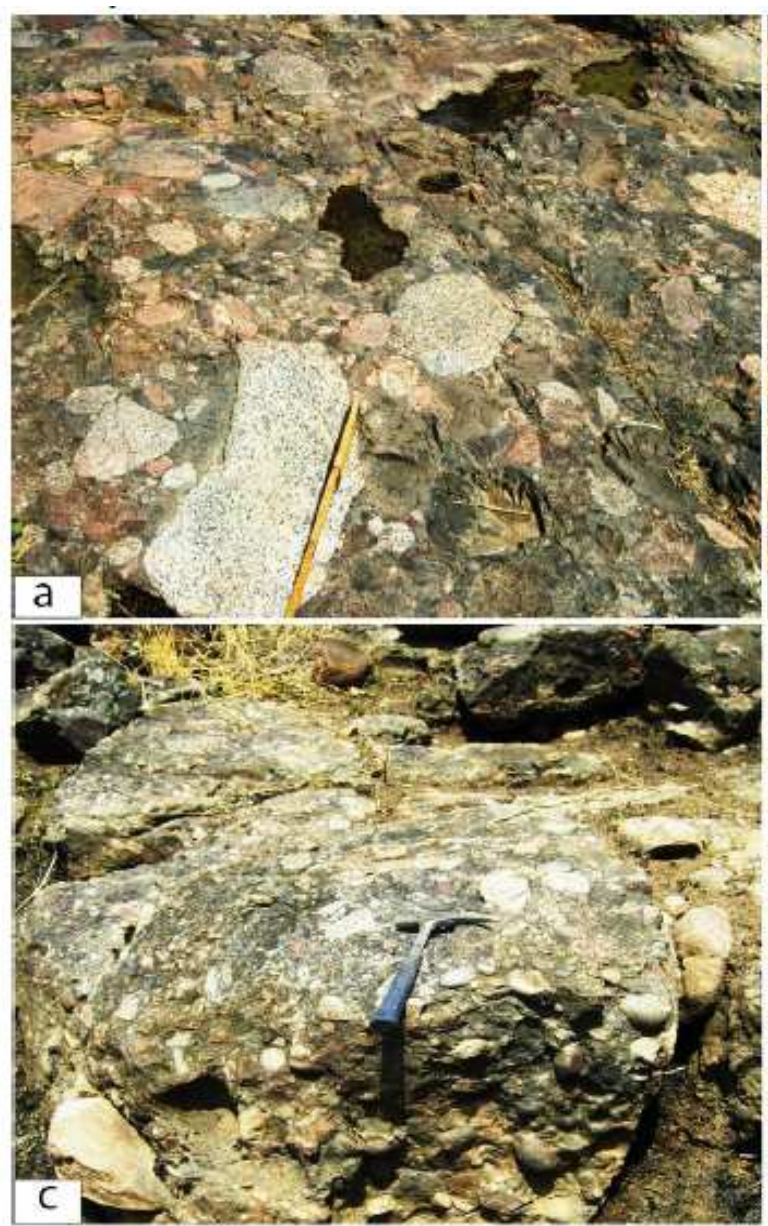

\section{Gg: Granules Composed of Massive Gravel}

The lithofacies Gg represents coarse conglomerates without structures composed of clasts, coarse gravel and pebbles (Fig. 2c). Deposits are chaotic, the pebbles predominate, varying from spherical, sub-angular and the color ranges from gray to black; sorting varies badly to medium. The clasts are ranked from granitic and basaltic origins; consolidated with cement composed by medium sandstone in parts and basalt flows. Deposits are massive and show no stratification. Miall (1978) and Rust (1978) interpret clasts-supported deposits by the cobbles and boulders as probably reflecting modes of transport by traction during aggradation of the longitudinal bars.

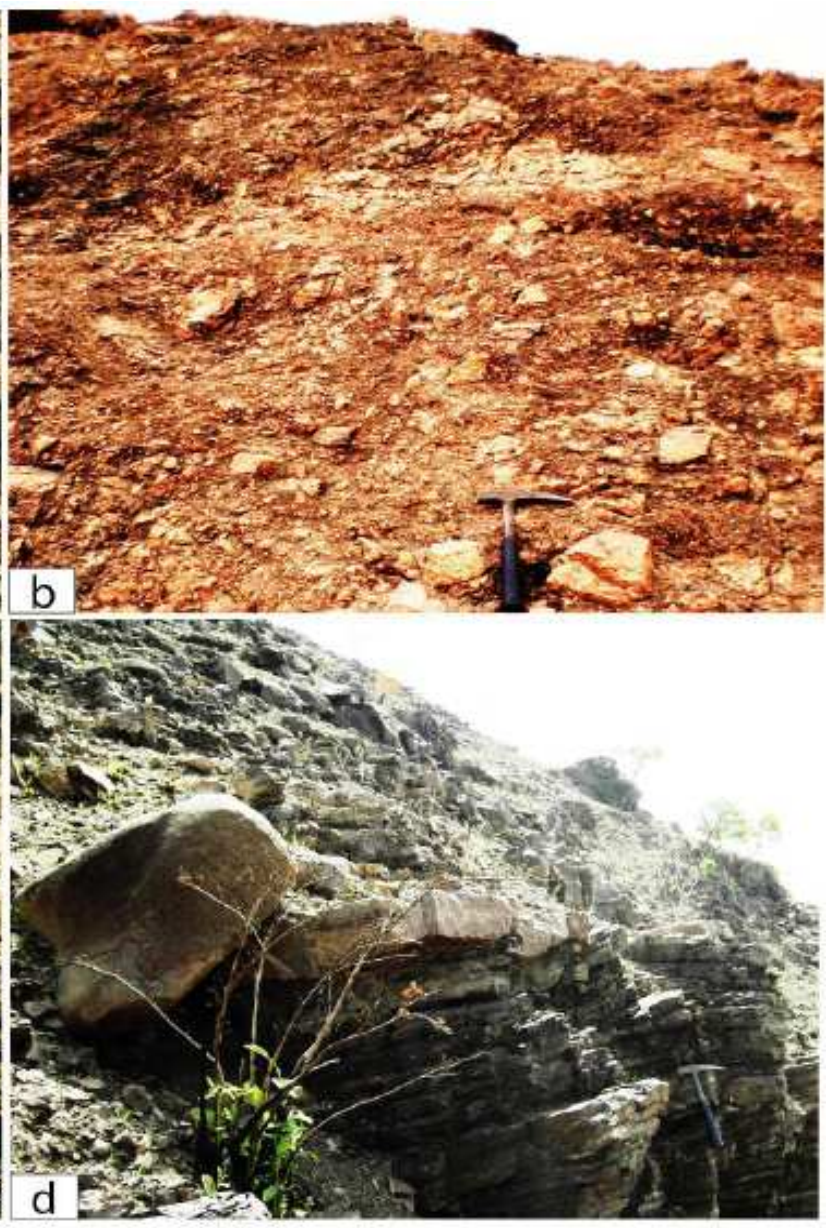

Fig. 2. Lithofacies types of Mangbai formation (a, b) Gb: Gb: Clast supported massive coble and boulder, (c) Gg, granules composed of massive gravel. (d) Fml: Massive laminated claystones 


\section{Sm: Massive Sand and Gravel Beds}

The lithofacies Sm consists of coarse to medium sandstone associated to massive sand and occasional breccias. The sands are angular to sub-angular, poorly rounded and poorly sorted. Sand beds are massive and showing no stratification. The cement is composed of a combination of poorly altered feldspars and fine sandstone. These formations represent "debris flow" deposits type with poor sorting. According to Miall (1996), the absence of sedimentary structures in the lithofacies $\mathrm{Sm}$ indicates that they are deposited by gravity or are rapid deposits during periods of high floods.

\section{Sh: Horizontal Layered Sandstones}

The lithofacies Sh represents medium to fine sandstone; color varies from gray to reddish. Sandstones are composed of angular to sub-angular quartz grains, moderately sorted and well cemented. Beds with a maximum thickness of $50 \mathrm{~cm}$ are horizontal laminated and alternating with claystones facies. The contact surfaces with claystones beds are slightly oxidized and encrusted, expressing a short period of non deposits. This lithofacies could indicate deposits in quiet environment. According to Miall (2010), lithofacies Sh may occur on the affected calm conditions in two depositional environments, the most important being the one that represents the upper bed in the transition from subcritical flow to supercritical.

\section{Fml: Massive Laminated Claystones}

The lithofacies Fml represents thin laminated claystones, compact and massive (Fig. 2d). The color move from dark gray to reddish. Claystones beds are alternating with fine to medium sandstone beds. The laminations are horizontal and parallel; the thickness of the beds varies from $1 \mathrm{~cm}$ to $50 \mathrm{~cm}$. the interpretation given by Miall (2010) indicates that the lithofacies type Fml represents suspension deposits and weak traction currents.

\subsection{Microfacies Study of the Mangbai Formation}

Microscopic analyzes of rocks collected from the formation of Mangbai allow us to observe a dominance of plagioclase phenocryst embedded in basaltic matrix (Fig. 3a and b); spherulite consists mainly of alkali feldspar with some quartz inclusions.

Some thin section shows vesicles (Fig. 3), the dark rims of the vesicles have been inferred to represent residual melt (cooled to glass, now alterated) that leaked into the gas bubbles during volcanic activity. Mineralogical and geochemical analyzes performed by (Bea et al., 1990) have characterize the volcanic sources rocks.

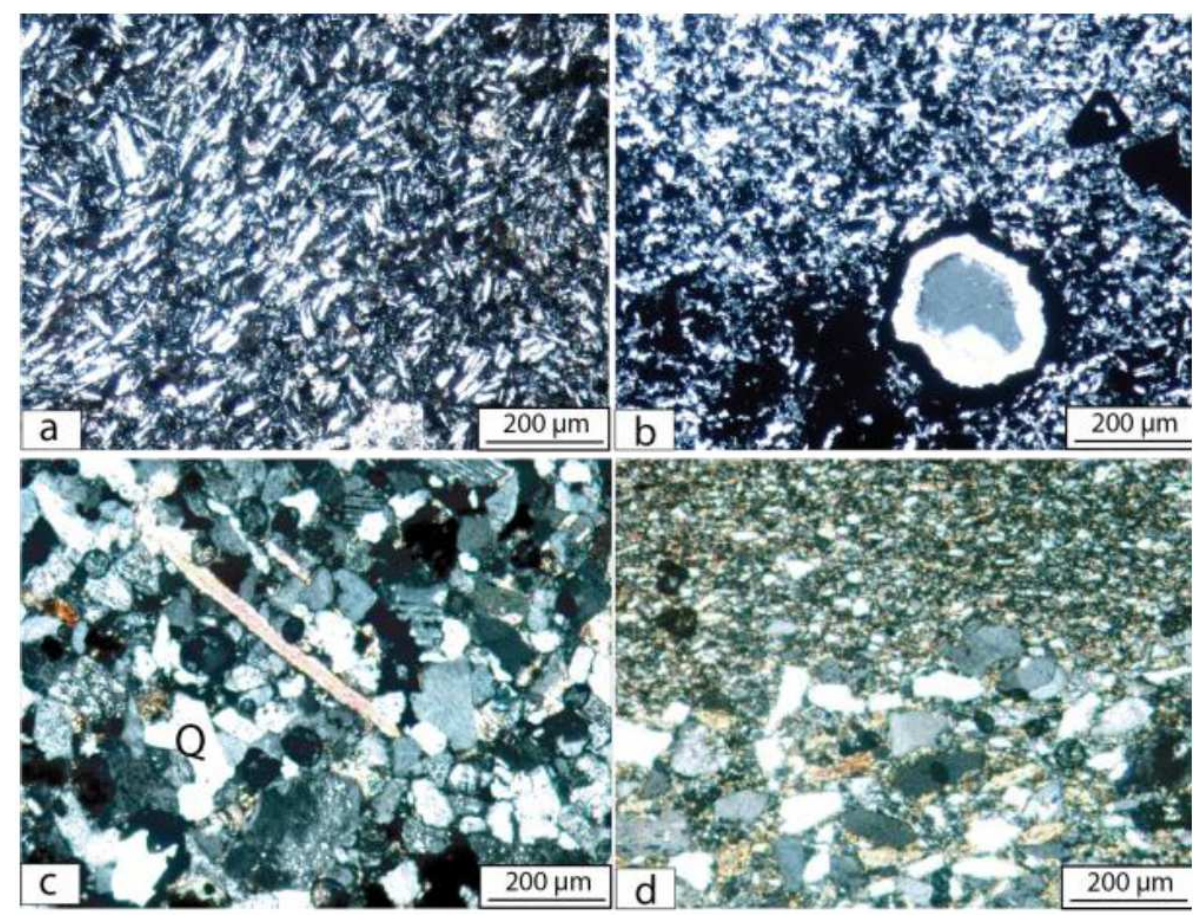

Fig. 3. Mangbai thin sections (a, b) plagioclase phenocryst (c) quartz arenite and (d) lithic arenite 


\section{DISCUSSION}

Volcano-sedimentary rocks of the Mangbai formation are made of mega-conglomerates with breccias of several meters from various sources: volcanic, granitic and gneissic. Also present conglomerates with blunted and sub-angular pebbles, which are overlain by claystones and fine sandstones. Basaltic deposits of probably different flows intersect the sedimentary deposits as well as trachytes and rhyolites intrusions. Miall (1966) and Rust (1978) conclude to deposits types from clast-by-clast accretion or debris flow due to lack of internal organization. Lava flows are cementing breccias of various origins and sedimentary rocks, bringing us to conclude to a multiphase's volcanisms. Medium to fine lithofacies ( $\mathrm{Sh}$ and $\mathrm{Fml}$ ) are results of deposited from alluvial fan and located at the lower part of the series. Bea et al. (1990) characterize Hossere Mangbai as a probably stratovolcano developed in a small sedimentary basin (Mayo Oulo). Well-rounded pebbles and blunted identified in the field are evidence of a long sediment transport along a river stream. This may indicate the presence of a former channel before the volcanic activity and/or tectonics. Cementation mechanisms with lava flow observed in the field suggest that the eruptive style of volcanism was mainly nonexplosive.

The volcano-sedimentary deposits of Mangbai Mountains were probably set up from the Panafrican and during the formation of West and Central Africa Rifts Systems (WCARS) which had played a major role in the development of early Cretaceous sedimentary basins of the region. Later, the faults system have facilitated the formation of North Cameroon half-graben basins Mayo Oulo, Babouri-No fossil record, be it in the location field or in thin section was observed in the volcano-sedimentary formations which were described as azoic and dated from Precambrian by Lasserre et al. (1977). Tillement (1972) and Bea et al. (1990) reported similar massifs with volcano-sedimentary deposits in the Northern part of the Poli sub-division (South of Garoua town) in the form of a chain of hills formed by sandstone and conglomerates interbedded with volcanic rocks; the set up mechanisms are similar to the Mangbai formation. The magmatic rocks are basically represented by basaltic lava flows interspersed with rhyolites, ignimbrites and tuffs.

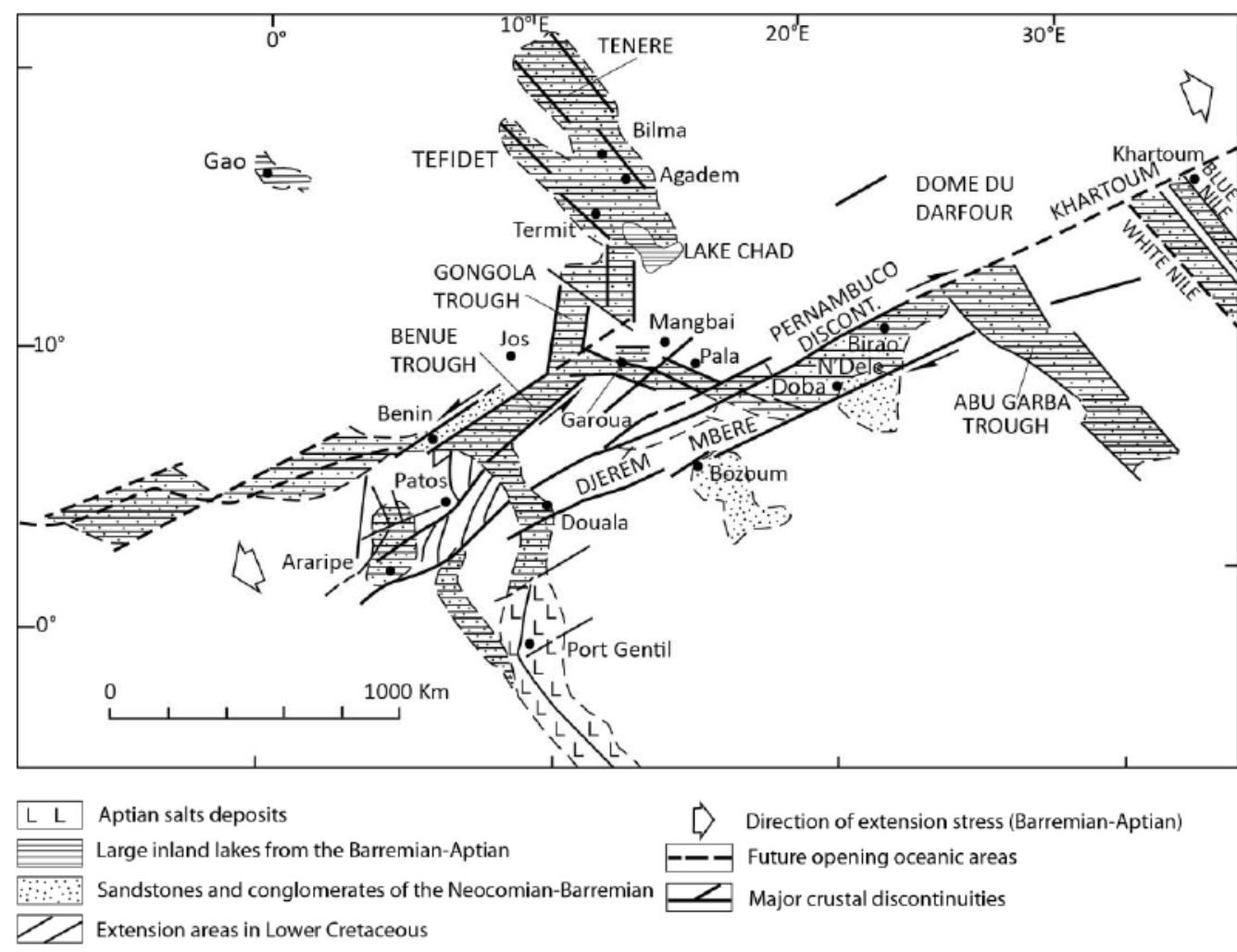

Fig. 4. Regional tectonic map showing evolution of rifts basins of NE South America and West and Central Africa (slightly modified and adapted after Popoff (1988) 
Figuil and the Cretaceous basins of Chad. Maurin and Guiraud (1990) characterize the Mayo Oulo and Babouri-Figuil basins as Lower Cretaceous asymmetrical synsedimentary synclines superposed on half-graben which open in response to N60 extension. These basins, including Mangbai Mountains, are located at the junction of WCARS (Fig. 4). Schull (1988) and Bosworth (1992) demonstrate that dextral transtensional motions along the western part of the Central Africa Rifts Systems (CARS) during the Early Cretaceous created the Salamat, Doseo and Doba basins. Mangbai formation, Mayo Oulo and Babouri-Figuil basins are located about $50-100 \mathrm{~km}$ to the west side of these regions.

\section{CONCLUSION}

Five disctinct lithofacies namely Gb-clast supported massive coble and boulder, Gg-granule compose of massive gravel, Sm-massive sand, Sh-horizontal layered sandstones, Fml-massive laminated claystones are characteristic of volcano-sedimentary deposit identified in the Mangbai formation. Coarse lithofacies were mainly influenced by source rock composition and gravity transportation mechanism. Medium to fine lithofacies are deposited from alluvial fan as gravity and debris flow and later cemented with fine sand and feldspaths alteration. The volcano-clastic formation of Mangbai was set up from the Precambrian age with establishment of Major faults structures systems. Later, in the Lower Cretaceous, this major tectonic event facilitated the installation of sedimentary basins and associate structures. Deposits in these basins are mainly clastic from the dismantling of the surrounding mountains.

\section{ACKNOWLEDGMENT}

Thin sections were made and analyzed using the laboratory of the University of Rouen in France. I am grateful to the St Justin foundation in Switzerland which partly supported this study.

\section{REFERENCES}

Bea, A., J.J. Cocheme, R. Trompette, P. Affaton and D. Soba et al., 1990. Grabens d'âge paléozoique inférieur et volcanisme tholéitique associé dans la région de garoua au nord-cameroun. J. Afr. Earth Sci., 10: 657-667. DOI: 10.1016/08995362(90)90032-A

Bosworth, W., 1992. Mesozoic and early tertiary rift tectonics in East Africa. Tectonophysics, 209: 115137. DOI: 10.1016/0040-1951(92)90014-W
Brunet, M., J. Dejax, A. Brillanceau, J. Congleton and W. Downs et al., 1988. Mise en évidence d'une sédimentation précoce d'âge Barrémien dans le fossé de la Bénoué en Afrique occidentale (Bassin du Mayo Oulo Léré, Cameroun), en relation avec l'ouverture de l'Atlantique Sud. C.R. Heb. Acad. Sci.-Paris, Série, 2: 1125-1130.

Lasserre, M., J.C. Baubron and J.M. Cantagrel, 1977. Existence d'une couverture non plissée d'âge paléozoïque inférieur, au sein de la zone mobile de 1'Afrique centrale: Age K/Ar des formations de type Mangbai. C. R. Acad. Sci., Paris. D, 284: 26672670.

Maurin, J.C. and R. Guiraud, 1989. Relations entre tectonique et sédimentation dans les bassins barrémo-aptiens du Nord Cameroun. C.R. Acad. Sci. Paris, 308: 787-792.

Maurin, J.C. and R. Guiraud, 1990. Relationships between tectonics and sedimentation in the Barremo-Aptian intracontinental basins of Northern Cameroon. J. Afr. Earth Sci., 10: 331-340. DOI: 10.1016/0899-5362(90)90064-L

Miall, A.D., 1978. Lithofacies Types and Vertical Profile Models in Braided River Deposits: A Summary. In: Fluvial Sedimentology, Miall, A.D. (Ed.), Canadian Society of Petroleum Geologists, Calgary, ISBN-10: 0920230032, pp: 597-604.

Miall, A.D., 1996. The Geology of Fluvial Deposits: Sedimentary Facies, Basin Analysis and Petroleum Geology. 1st Edn., Springer, Berlin, ISBN-10: 3642082114, pp: 582.

Miall, A.D., 2010. The Geology of Stratigraphic Sequences. 1st Edn., Springer, Heidelberg, ISBN10: 3642050271 , pp: 544.

Montigny, R., I. Ngounouno and B. Deruelle, 2004. Âges K Ar des roches magmatiques du fossé de Garoua (Cameroun): Leur place dans le cadre de la « Ligne du Cameroun». C. R. Geosci., 336: 14631471. DOI: $10.1016 /$ j.crte.2004.08.005

Ndjeng, E. and M. Brunet, 1994. Deux appareils datés de l'Hauterivien-Barrémien dans le Nord-Cameroun (Fossé de la Bénoué): Les bassins de Babouri-Figuil et du Mayo oulo-Léré. Annales de la faculté des sciences, Uni. de Yaoundé; hors série ${ }^{\circ}{ }^{\circ}$, Chimie et Sciences Naturelles, pp: 97-106.

Ndjeng, E. and M. Brunet, 1998. Modèles d'évolution géodynamique de deux bassins de l'HauterivienBarrémien du Nord-Cameroun: Les bassins de Babouri-Figuil et du Mayo Oulo-Léré (Fossé de la Bénoué). GEOCAM, Presse Univ. Yaoundé I. 
Popoff, M., 1988. Du Gondwana à l'Atlantique Sud; les connexions du fossé de la Bénoué avec les bassins $\mathrm{du}$ Nord-Est brésilien jusqu'à l'ouverture du golfe de Guinée au Cretacé inférieur. J. Afr. Earth Sci., 7: 409-431. DOI: 10.1016/0899-5362(88)90086-3

Rust, 1978. Depositional models for braided rivers. Sedimentology in Fluvial 7 Sedimentology Can. Soc. Pet. Geol. Mem., 5: 605-625.
Schull, T.J., 1988. Rift basins of interior Sudan; petroleum exploration and discovery. AAPG Bull., 72: 1128-1142.

Tillement, B., 1972. Hydrogéologie du Nord-Cameroun. Thèse de Doctorat, Univ. de Lyon. 